\title{
THE ASSESSMENT OF ENVIRONMENTAL AND MEDICAL CONSEQUENCES OF THE ATMOSPHERE POLLUTION WITH PETROLEUM PRODUCTS
}

\begin{abstract}
The article deals with the dependence between atmospheric air pollution, resulted by the activity of fuel filling stations, and the morbidity of the population at the adjacent areas. The major human health consequences, arising from the inhalation of volatile components of commercial petroleum products, have been analyzed. It has been established that the content of petroleum products in the atmosphere in the zone of fuel filling stations influence exceeds the maximum permissible and corresponding background values. With the help of mathematical analysis it is determined that at these territories the risk for the population to get diseased with respiratory forms of allergy, asthma and chronic respiratory system disorders is higher, as compared with the territories outside the influence of fuel filling stations.
\end{abstract}

Key words: air pollution, morbidity, cohort analysis, health risks, fuel filling stations, petroleum products.

М.М. Радомська, канд. техн. наук, доцент, І.В. Горобцов (Національний авіаційний університет)

\section{ОЦНКА МЕДИКО-ЕКОЛОГІЧНИХ НАСЛІДКІВ ЗАБРУДНЕННЯ АТМОСФЕРНОГО ПОВІТРЯ НАФТОПРОДУКТАМИ}

\begin{abstract}
У статті розглядається взаємозв'язок забруднення атмосферного повітря внаслідок діяльності паливозаправних об’єктів і захворюваності населення на прилеглих ділянках. Проаналізовані основні наслідки для здоров'я, що можуть виникати при інгаляційному надходженні в організм людини летких компонентів товарних нафтопродуктів. Встановлено, що рівні вмісту нафтопродуктів у атмосферному повітрі в зоні впливу АЗС перевищують гранично допустимі та відповідні фонові значення. За допомогою математичного аналізу визначено, що на відповідних територіях ризик захворювання населення на респіраторні форми алергії, астму та хронічні розлади респіраторної системи є вищою, порівняно $з$ територіями поза впливом АЗС.
\end{abstract}

Ключові слова: забруднення повітря, захворюваність, когортний аналіз, ризики для здоров’я, паливозаправні об'єкти, нафтопродукти.

Introduction. According to estimates of the US Environmental Protection Agency, exposure to toxic substances, that pollute the air, every year causes 1700-2700 kinds of diseases [1]. In recent years, the trend of growth of cancer, respiratory diseases, and various kinds of allergies, cardiovascular diseases, metabolic and nervous disorders is observed. Particularly alarming indicators - are infant morbidity and reduction of life expectancy.

The main source of negative impacts on the territory of urban ecosystems is transport together with its maintenance network. A considerable part of urban air pollutants are released from the territories of reservoir parks of fuel filling stations (FFS) as well as the roadbed and adjoining areas at an altitude of one and a half meters This is the height of human breathing, and thus, people are forced to inhale those substances. Improper design and construction of transport systems and fuel filling facilities, poor insulation of reservoirs, emergency situations, violation of rules of technological processes implementation - all of this leads to the release of toxic substances that are dangerous for the workers of FFS and residents of the surrounding areas.

Problem formulation. In 2014-2015 the Ukrainian market of FFS totaled approximately seven thousand service stations and complexes [2]. The problem of increasing number of fuel filling stations in cities has worried citizens for a long time in all parts of the world [3]. The construction of such facilities in the residential areas of cities on the one hand is promising as the consumer is nearby, but it is also problematic - to withstand all the requirements for the construction of an object often becomes a difficult task $[4,5]$. European standards allow to construct FFS close to buildings, especially business ones, but in Ukraine they are more stringent. However, it should be accounted that in Europe there are also more stringent requirements regarding the environmental characteristics of the filling stations [6]. 
With a constant growth of car park facilities the efforts aimed at reduction of petroleum products losses become of major importance. It should be noted that modern oil products, which are produced and currently used, contain 10-15 times lower concentrations of harmful substances than 20 years ago $[7,8]$. At the same time the list of substances, contents of which must be controlled, is constantly expanding.

Yet it should be kept in mind that the chemical compounds emitted could transform in the atmosphere into toxic substances two times more hazardous than the original fuel vapor components, as a result of photochemical reactions. That is why research of the level of air pollution in the areas of compact population residence is critical for maintaining the level of environmental safety that does not endanger the health and life quality of people.

Thus, the purpose of the research is to determine the impact of FFS on the atmospheric air quality and its potential health effects, analyze medical situation in the areas affected by the FFS and develop recommendations for the mitigation of their negative environmental impacts.

Analysis of previous research. Previously, the issues of the influence of the FFS activities on the environment were Belyaev A.Yu., Franchuk G.M., Yakovlev V.S., Margolin E.M., Sidorov E.A., Govorun A.G., as well as foreign specialist Mshelia A.M. et al., Ohlrogge K. et al., Nieminen P.M. The scientists have paid special attention to the means of reducing the losses of petroleum products through evaporation, which leads to the pollution of atmospheric air (Abuzova F.F., Korshak A.A., Konstantinov N.N., Chernikin V.I., Gizzatov M.A., Kulagin A.V., Tsegelsky V.G.).

Thus, the main causes of air pollution from fuel reservoirs (as well as the overall pollution from the FFS) are reservoirs "breathings" - the process of displacement of petroleum products vapors from the gas space of fuel reservoir or air supply from the outside through the vacuum creation in the gas space of the tank. Another cause of pollution linked with reservoirs, which deserves attention, may be the ventilation of tanks in the process of their maintenance, manually or with the help of automated system [5,9]. An important issue is wrong operation of equipment, leading to failures [3]. Rain and run-off waters at FFS usually carry petroleum products, which form the film on the surfaces of water that actively evaporates from accumulation tanks [5, 7].

Mobile sources of pollution are considered to be consumers of the fuel at FFS, which cause pollution with the emissions from the vehicle fuel tank at the moment of fueling due to displacement of the air trapped in, as well as through the operation of engines at idle, acceleration and deceleration modes, due to incomplete combustion of fuel [9].

Among the major reasons of liquid petroleum products release into the environment at the FFS the following ones can be distinguished: overflow of reservoirs during filling and motor fuel tanks during fueling; separation of bindings and failure in reservoirs pipelines due to aging and wearing of metal; malfunction and damage of dispensing taps, pressure hoses, breathing valves, decompression of reservoirs; degradation of equipment; insufficient technical training and discipline of personnel [10]. Factors affecting the formation of air pollution as a result of spilled petrochemicals evaporation are very diverse and include: volatility of petroleum products; type and condition of evaporation surface; intensity of air masses circulation; air humidity and its saturation with other gases; temperature and pressure; chemical composition of emissions [11].

The chemical composition of gasoline is characterized by hydrocarbon group composition, i.e. content of aromatic, olefinic, naphthenic and paraffinic hydrocarbons in them. Apart from hydrocarbons in gasoline, heteroatomic hydrocarbon compounds, which include sulfur, oxygen and nitrogen, are found there in small amounts [9]. As a result, the air around the FFS includes diverse, unusual for it compounds, each of which differs in its contribution to overall pollution and by the range of effects, but the basic components remain the same - propane and butane, as well as the actual mixture of hydrocarbons called "gasoline". Individual attention should be paid to volatile aromatic compounds present in vapors of gasoline, namely benzene, xylene, toluene, cumene, ethylbenzene. Other highly toxic components are formaldehyde and inorganic compounds-satellites of operations with petroleum products: oxides of nitrogen, sulfur and carbon. To choose the target health disorders for further analysis, the data on the toxicity of these components has been analyzed to reflect the most important medical and biological consequences of exposition to these substances by contact and inhalation. 
The incidence of illness of children with acute respiratory diseases and chronic bronchopulmonary system disorders, pathology of respiratory system (including pneumonia), acute respiratory infections, catarrhs of the upper respiratory tract, bronchial asthma and allergic pathologies significantly correlates with the level of air pollution in industrial city districts [12-15]. For example, the frequency of allergic diseases among people living in the area, located 100 meters from the source of pollution could be 3 times higher than that of $500 \mathrm{~m}$. The increase in the allergic diseases incidence may be observed even at the distance over $10 \mathrm{~km}$ from the production site (pollution source). And the growth of appeals of the residents about asthma attacks may increase six-fold in the days of particularly heavy pollution [16-19].

So, the major medical and biological effects, for which it was established a potential link with toxic volatile components of commercial fuel products, based on the literature analysis conducted, are asthma and other chronic disorders of the respiratory system, changes in blood composition and symptoms of allergic disorders (of contact and respiratory origin).

Methods and materials. In order to evaluate potential human health consequences from the activity of FFS it is necessary to analyze the content of petroleum products in the air. It is important to note that the term "petroleum products" is roughly limited to hydrocarbon fraction consisting of nonpolar and low polar aliphatic, aromatic, cyclic hydrocarbons, which makes it difficult to choose efficient methods for studying this type of pollution in any component of the environment, including the air [9].

In the process of air pollution determination one of the primary and most crucial requirements was speed of measurements, that will allow to obtain accurate results in a short time and cover a large number of objects within the same weather conditions (because they significantly affect on the distribution of pollutants). Therefore, for the analysis of air pollution with petroleum products the colorimetric method was chosen. The method involves the acquisition of the pollutant from the air and its selective chemical reaction with the indicator powder. The resulted colored products of reaction reflect the concentration of pollutant with the length of the indicator powder layer, which has changed the original color. The final result is an arithmetic mean of three consequent measurements. To define the level of pollution the obtained data were compared with the MPC $=$ $100 \mathrm{mg} / \mathrm{m}^{3}$, defined as a standard for working conditions according to the DSTU-NB A 3.2-1:2007 "Instruction concerning determination of dangerous and harm fullfactors and proofing against influent thereof in production of building materials and products and their application in the course of erection and utilizations of constructional projects". The standard was applied as the colorimetric method of air pollution testing works within the corresponding range of concentrations and is not sensitive to the content of petrol permissible according to the standards for atmospheric air at residential territories. However, the MPC for residential territories is much lower than the one for working area and this allows making conclusions about the presence of health hazard in case of its accidence, accounting the process of pollutant distribution in the air.

The statistical analysis of the relations in the "environment-health" system was based on cohort analysis and relative health risk assessment. Cohort analysis is used to assess the relative health risk for small contingents of people who are placed under the influence or are in contact with harmful environmental factors. It provides an opportunity to establish the reliability of the differences between basic and control groups, which differ in terms of influence of the studied factors [20].

To perform cohort analysis by $\chi^{2}$-algorythm it is necessary to group the available data on morbidity levels and perform the calculation using the formula:

$$
\chi^{2}=\frac{(A \cdot D-B \cdot C)^{2} \cdot(A+B+C+D)}{(A+B) \cdot(C+D) \cdot(A+C) \cdot(B+D)},
$$

where $\mathrm{A}$ is a number of diseased people in contact with the harmful factor; $\mathrm{B}$ - number of healthy people in contact with the harmful factor; $\mathrm{C}$ - number of diseased people out of the contact with harmful factor; $\mathrm{D}$ - number of healthy people out of contact with the harmful factor

If the differences are reliable $(\mathrm{P}<0.05) \chi^{2}$-criterion must be greater than 3.84 and in case of $\mathrm{P}<0.01 \chi^{2}$-criterion must be greater than $6.63[20]$. 
The value of the relative risk is given by:

$$
R=\frac{A \cdot D}{B \cdot C}
$$

The resulting value indicates how much the risk of disease for people who are in contact with harmful factor is higher compared to the control group.

Results and discussions. To perform the investigation 20 fuel filling stations of Desnianskiy and Darnitskiy districts of Kyiv, located near the residential buildings were selected. These filling stations are located in the most densely populated residential areas and represent the essence of the studied problem. In order to collect and analyze medical data apartment buildings in the impact areas of these FFS were divided according to their attachment to medical polyclinics of respective districts.

The concentration of pollutants in the areas affected by fuel filling stations was studied in the points at the border of filling stations territories (at the distance $50 \mathrm{~m}$ from the actual limit of the FFS) in July and September 2016, since the possibility of measurements with indicator tubes is limited by temperature conditions. Also relevant measurements were performed in control areas distant from any FFS by $2-2.5 \mathrm{~km}$ for isolating the impact of highways (Fig.1).

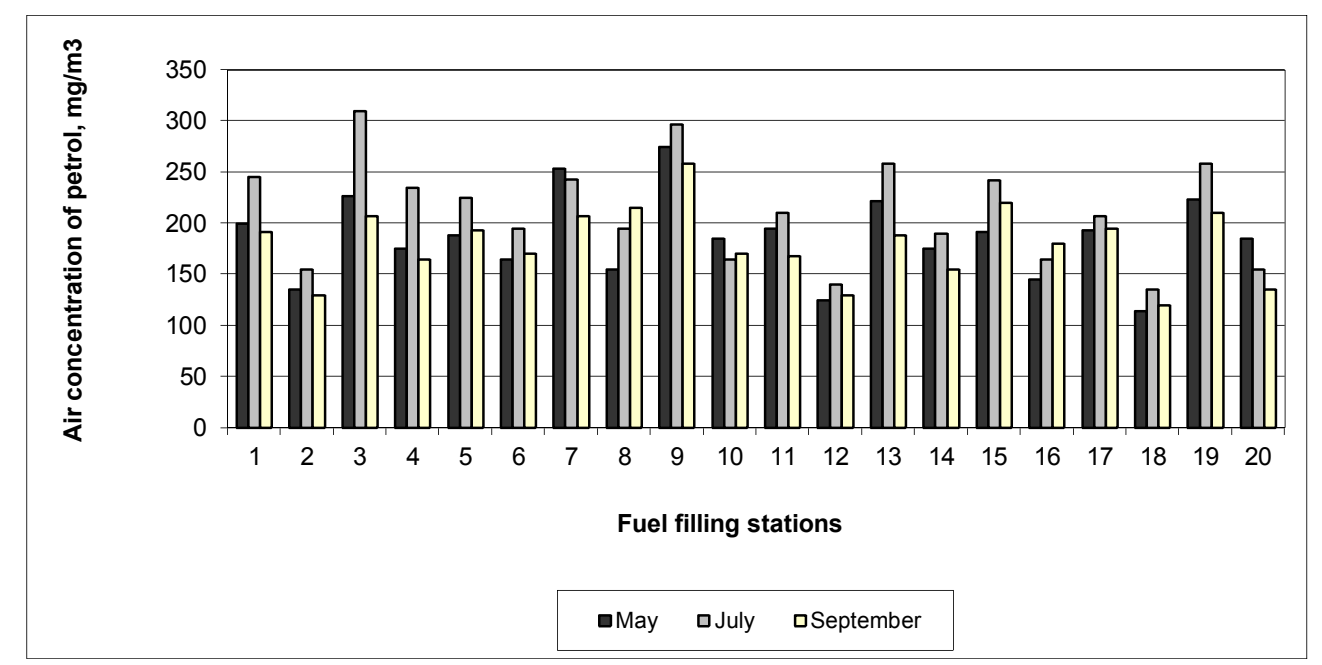

Fig. 1 - The results of air pollution testing

Thus, comparisons of the content of gasoline in the areas affected by filling stations, with the relevant concentrations at control areas show a clear excess - from 1,2 to 2,07. The comparison with the relevant MPC standards for gasoline gives higher values, which vary from 1.14 to 2.58. A slight excess above the standards is as well established for the absolute majority of values at control areas (from 89,3 to $105,6 \mathrm{mg} / \mathrm{m}^{3}$ ) due to the influence of busy highways.

The data on the morbidity of population within the defined groups of diseases have been collected at corresponding polyclinics and analyzed to define the level of dependence between them and air pollution and the potential health risks has been determined. The information obtained included primary statistical information given by the departments of statistics at the chosen polyclinics. It represents the number of new cases of the health disorders diagnosed since the establishment of FFS at the studied areas. The control data were obtained from the medical districts without close proximity of the FFS for the same period of time. The number of cases falling into each category was defined by the polyclinics authority according to the International Statistical Classification of Diseases and Related Health Problems, 10th revision (ICD-10) and included J40-J47 - chronic diseases of the lower respiratory tract and J60-J70 - lung diseases caused by external agents; D50-D89 - diseases of blood, blood-forming organs and certain disorders involving the immune mechanism; T78.4 - Allergy, unspecified.

The findings indicate the importance of differences in the incidence of allergies, asthma and other chronic disorders of the respiratory system (in most cases with accuracy of $99 \%$ ), while 
changes in blood composition are not determined only by the influence of pollutants coming from the territory of the FFS, and do not differ on the experimental and control areas (Table 1). The magnitude of the relative risk shows that for the people, living in the area of influence of filling stations, the probability of getting ill with asthma or allergies is higher, comparatively to the population of control regions, by $20-30 \%$.

Table 1

Cohort analysis results

\begin{tabular}{|c|l|c|c|c|c|c|c|}
\hline \multirow{2}{*}{ № } & \multicolumn{1}{|c|}{ Group of disease } & \multicolumn{6}{|c|}{ Experimental area } \\
\cline { 3 - 8 } & \multicolumn{2}{|c|}{ №1 } & \multicolumn{2}{c|}{ №2 } & \multicolumn{2}{c|}{ №3 } \\
\cline { 3 - 8 } & $\chi^{2}$ & $\mathrm{R}$ & $\chi^{2}$ & $\mathrm{R}$ & $\chi^{2}$ & $\mathrm{R}$ \\
\hline \multirow{2}{*}{1} & $\begin{array}{l}\text { Asthma and other chronic disorders of } \\
\text { the respiratory system }\end{array}$ & 4.91 & 1.21 & 14.73 & 1.29 & 11.69 & 1.27 \\
\hline 2 & Changes in blood composition & 0.25 & 1 & 2.0 & 1 & 0.009 & 1 \\
\hline 3 & Symptoms of allergic diseases & 13.05 & 1.34 & 10.79 & 1.16 & 7.4 & 1.18 \\
\hline
\end{tabular}

Considering the obtained results, the introduction of additional nature protecting measures at the FFS is necessary for reducing pollutants emissions and health risks:

a)maintenance of complete technical serviceability of reservoirs, respiratory valves, technological equipment and pipelines, ensuring their integrity;

b) accuracy of draining and filling operations;

c)installation of emission prevention equipment on the reservoirs;

d) equipment of FFS reservoirs and fuel dispensers with the systems (installations) of capturing (removal) and recovery of gasoline vapors;

e)organization of regular air monitoring over in the impact areas of filling stations.

Conclusions. One of the most serious impacts on the environment due to the work of FFS is the pollution of air. The main sources of pollution from the FFS are stationary (equipment) or mobile (vehicles), and organized ("breathings" and ventilation) or accidental (spills, failures, malfunctions and human factor). The impacts of the air pollution could be very diverse and, in most cases, are extremely harmful.

The toxicological profile of the gross components of gasoline and diesel fuels includes disruption of the central nervous system, respiratory, reproductive systems violation and metabolic disorders, hemopoietic organs damage and carcinogenic effects.

To study the level of air pollution under the influence of FFS colorimetric method using indicator tubes was applied. The air pollution testing was conducted at 20 different FFS in Desnyansky and Darnytsky districts of Kyiv. The results showed that the air content of gasoline exceeds both background and standard (MPC) values.

The analysis of morbidity at the territories adjoined to the studied FFS by the method of cohort analysis demonstrated a considerably higher incidence of allergic diseases, asthma and other chronic disorders of the respiratory system (with accuracy of $99 \%$ ), while changes in the blood composition are not determined solely by the influence of pollutants coming from the territories the FFS, and did not differ on experimental and control areas. The level of the relative risk shows that, the probability of getting ill with asthma or allergies is higher by $20-30 \%$ for the population living in the areas of the FFS influence, as compared to the population of control areas.

The recommendations for the improvement of environmental situation offered include: improvement of equipment technical maintenance, increased control over performance of technological operations and development of environmental monitoring at the given objects. 


\section{References:}

1. Beelen, R., Hoek, G., Houthuijs, D. The joint association of air pollution and noise from road traffic with cardiovascular mortality in a cohort study // Occupational and Environmental Medicine. - 2009. - №66. - P. 243-250.

2. Винничук Ю. Заправщики Украины // Бизнес цензор. - 2016. - №3. - С. 14-19.

3. Mshelia, A.M., Abdullahi, J., Dawha, E.D. Environmental Effects of Petrol Stations at Close Proximities to Residential Buildings in Maiduguri and Jere, Borno State, Nigeria // IOSR Journal Of Humanities And Social Science. - 2015. - Vol. 20. - Issue 4. - PP. 1-8

DOI: $10.9790 / 0837-20440108$.

4. Лісафін В.П., Люта Н.В. Типові розрахунки процесів приймання, зберігання та розподілу нафти і нафтопродуктів. - Івано-Франківськ: Факел, 2003. - 248 с.

5. Беляев, А.Ю. О загрязнении поверхностного стока территорий автозаправочных комплексов // Сборник «Денисовские чтения». - М.: МГСУ, 2001. - С. 132-137.

6. Nieminen, P.M. Environmental Protection Standards at Petrol Stations: A comparative study between Finland and selected European countries. Tampere: University of Technology, 2015. - 164 p.

7. Долина Л.Ф. Современная технология и сооружения для очистки нефтесодержащих сточных вод. - Днепропетровск: Континент, 2005. - 296 с.

8. Іщук Ю.Л., Кобилянський Є.В., Кочірко Б.Ф. Біорозщеплюваність нафтопродуктів і проблеми біосфери // Нафтова і газова промисловість. - 2004. - №1. - С. 57-60.

9. Guidelines for soil, groundwater and surface water protection and vapour emissions control at petrol filling station. - London: Institute of Petroleum, 2002. $-72 \mathrm{p}$.

10. Миндюк В. Д. Аналіз причин появи експлуатаційних дефектів в процесі роботи трубопроводів // Розвідка і розробка нафтових і газових родовищ. - 2006. - №3. - С. 27-31.

11. Ohlrogge, K., Wind, J. Hassel D. New technology for emission reduction at petrol stations. - IUAPPA The World Clean Air Congress, 2000. - PP. 418-425

12. Cesaroni, G., Badaloni, C., Porta, D., Forastiere, F., Perucci, C.A. Comparison between various indices of exposure to traffic-related air pollution and their impact on respiratory health in adults // Occupational and Environmental Medicine. - 2008. - №65. - P. 683-690.

13. Finkelstein M. M., Jerrett, M., Sears, M.R. Traffic Air Pollution and Mortality Rate Advancement Periods // American Journal of Epidemiology. - 2004. - №160. - P. 173-177.

14. Rosenlund M., Forastiere, F., Porta, D. Traffic-related air pollution in relation to respiratory symptoms, allergic sensitisation and lung function in schoolchildren // Thorax. - 2009. - №64. - P. 573-580.

15. Jerrett, M. Does traffic-related air pollution contribute to respiratory disease formation in children? // European Respiratory Journal. - 2007. - №29. - P. 825-826.

16. Турбина Е.С. Влияние содержащихся в атмосферном воздухе взвешенных веществ на заболеваемость детей-дошкольников // Вестник Приамурского государственного университета им. Шолом-Алейхема. - 2010. - №2.

17. Тулякова О.В. Влияние загрязнения атмосферного воздуха на особенности заболеваемости и психического развития детей // Курский научно-практический вестник "Человек и его здоровье”. - 2012. - №1. - С. 67-72.

18. Ерошина К. Роль экологических и социальных факторов в возникновении заболеваний органов дыхательных путей у детей младшего школьного возраста г. Москвы / К. Ерошина, М. Макки, П. Уилкинсон. // Медицина. - 2013. - №3. - С. 57-71.

19. Johnson G.C., Ownby D.R., Zoratti E.M. et al. Environmental epidemiology of pediatric asthma and allergy // Epidemiologic Reviews. - 2002. - Vol.24, №2. - P.154-175.

20. Чумак В.Л., Іванов С.В., Максимюк М.Р. Основи наукових досліджень. - Київ: HAУ, 2009. - 304 c. 


\section{References:}

1. Beelen, R. (2009), "The joint association of air pollution and noise from road traffic with cardiovascular mortality in a cohort study", Occupational and Environmental Medicine, 2009, issue 66 , pp. 243-250.

2. Vinnichuk, Yu. (2016), "Fuellers of Ukraine", Business censor, 2016, Vol. 3, pp. 14-19.

3. Mshelia, A.M., Abdullahi, J., Dawha, E.D. (2015), Environmental Effects of Petrol Stations at Close Proximities to Residential Buildings in Maiduguri and Jere, Borno State, Nigeria. IOSR Journal Of Humanities And Social Science, Vol. 20, Issue 4, 1-8.

DOI: $10.9790 / 0837-20440108$.

4. Lisafin, V.P., Lyuta, N.V. (2003), Typovi rozrakhunky protsesiv pryymannya, zberihannya ta rozpodilu nafty i naftoproduktiv, [Typical calculations of the processes of reception, storage and distribution of oil and petroleum products], Fakel, Ivano-Frankivsk, Ukraine.

5. Belyaev, A.Yu. (2001), O zagryaznenii poverkhnostnogo stoka territoriy avtozapravochnykh kompleksov, [On contamination of surface runoff of the territories of refueling complexes], "Denisov Readings", MGSU, Moscow, Russia.

6. Nieminen, P.M. (2005). Environmental Protection Standards at Petrol Stations: A comparative study between Finland and selected European countries. Tampere University of Technology. Tampere, Finland.

7. Valley, L.F. (2005), Sovremennaya tekhnologiya i sooruzheniya dlya ochistki neftesoderzhashchikh stochnykh vod [Modern technology and facilities for cleaning oily wastewater], Continent, Dnepropetrovsk, Ukraine.

8. Ishchuk, Yu.L., Kobilyansky, Ye.V., Kochirko, B.F. (2004), Biodegradability of petroleum products and biosphere problems, Oil and gas industry, issue 1, pp. 57-60.

9. Guidelines for soil, groundwater and surface water protection and vapour emissions control at petrol filling station (2002), Institute of Petroleum, London, United Kingdom.

10. Mindyuk, V.D. (2006) Analysis of the causes of operational defects in the process of pipelines, Exploration and development of oil and gas fields, Issue 3, pp.27-31.

11. Ohlrogge, K., Wind, J. Hassel D. (2000), New technology for emission reduction at petrol stations. IUAPPA The World Clean Air Congress, pp.418-425.

12. Cesaroni, G., Badaloni, C., Porta, D., Forastiere, F., Perucci, C.A. (2008), Comparison between various indices of exposure to traffic-related air pollution and their impact on respiratory health in adults, Occupational and Environmental Medicine, Issue 65, pp.683-690.

13. Finkelstein, M.M., Jerrett, M., Sears, M.R. (2004), Traffic Air Pollution and Mortality Rate Advancement Periods, American Journal of Epidemiology, issue 160, pp. 173-177.

14. Rosenlund M., Forastiere, F., Porta, D. (2009), Traffic-related air pollution in relation to respiratory symptoms, allergic sensitisation and lung function in schoolchildren, Thorax, issue 64, pp. 573-580.

15. Jerrett, M. (2007), Does traffic-related air pollution contribute to respiratory disease formation in children? European Respiratory Journal, issue 29, pp. 825-826.

16. Турбина, Е.С. (2010), Влияние содержащихся в атмосферном воздухе взвешенных веществ на заболеваемость детей-дошкольников, Вестник Приамурского государственного университета им. Шолом-Алейхема, issue 2, pp. 66-71.

17. Tulyakova, O.V. (2012) Influence of atmospheric air pollution on morbidity and mental development of children, Man and his health, issue 1, pp. 42-49.

18. Eroshina, K., McKee, M., Wilkinson, P. (2013), The role of environmental and social factors in the development of airway diseases in young children of school age in Moscow, Medicine, issue 3, pp. 57-71.

19. Johnson G.C., Ownby D.R., Zoratti E.M. et al. (2002), Environmental epidemiology of pediatric asthma and allergy, Epidemiologic Reviews, Vol.24, issue 2, pp.154-175.

20. Chumak, V.L., Ivanov, S.V., Maksimyuk, M.R. (2009), Osnovy naukovykh doslidzhen [Fundamentals of Scientific Research], National Aviation University, Kyiv, Ukraine. 